\title{
HOLISTIC REDEMPTIVE PASTORAL MINISTRY IN THE FRAGMENTED TRANSIT HALL OF EXISTENCE
}

\author{
Author: \\ Johann-Albrecht Meylahn ${ }^{1}$
}

\section{Affiliation:}

${ }^{1}$ Department of Practical

Theology, University of

Pretoria, South Africa

\section{Correspondence to:}

Johann-Albrecht Meylahn

email:

jmeylahn@lantic.net

\section{Postal address:}

PO Box 14885, Lyttelton

0140, South Africa

\section{Keywords:}

capitalism; discourse

theory; fragmentation; globalisation; identity; Lacan; postmodernity

\section{Dates:}

Received: 08 Oct. 2009

Accepted: 30 Jan. 2010

Published: 01 Oct. 2010

How to cite this article:

Meylahn, J.-A., 2010,

'Holistic redemptive pastoral ministry in the fragmented transit hall of existence', HTS Teologiese Studies/Theological Studies 66(1), Art. \#426, 9 pages. DOI: $10.4102 /$ hts.v66i1.426

This article is available at:

http://www.hts.org.za (c) 2010. The Authors. Licensee: OpenJournals Publishing. This work is licensed under the Creative Commons Attribution License.

\section{ABSTRACT}

The grand narratives have all but gone - what is left are numerous narratives, each addressing a certain aspect of our lives; there is a different narrative for our professional lives, another for our family lives, for our social lives and yet another for our spiritual lives. We find ourselves in this 'transit hall', forever changing flights or trains, depending on which narrative sphere we are entering or leaving. In each narrative we take on a different character, defined and shaped by the specificities of that narrative. Thus, 'transition' in the sense of change can no longer be understood as only linear, but as constant and multidimensional. With the use of Lacan's discourse theory, this fragmented existence will be unpacked and a redemptive alternative sought.

This paper is an attempt to address this multi-narrative existence without imposing yet another grand narrative. Thus it focuses on offering a narrative space that is, (1) holistic, in the sense that it addresses all the different narratives, (2) pastoral, in that it addresses the person and (3) redemptive, in that it offers something new, meaningful and hopeful. Such a narrative space moves the church from its 'ghetto mindset', where traditions and values are maintained, to being fully open and vulnerable to the present reality, whilst yearning for the Messianic to reveal an alternative future.

\section{A TEXT BEHIND THE TEXT, OR A PROLOGUE}

We live in a socio-political cultural environment in which we are made to believe that the grand narratives have all but gone - that there is no such thing as universal truth and, therefore, subjects are social and localised constructions. It seems as though the grand narratives of modernity have disappeared - and with them, some scholars would argue, the 'subject' - leaving only characters that enact the roles of their various narratives. We find ourselves in this transit hall, forever changing flights or trains depending on which narrative sphere we are leaving or entering and so we take on a different character, defined and shaped by the specificities of each particular narrative. Thus, 'transition' in the sense of change, can no longer just be understood as linear, but as constant and multidimensional.

In this article, I will make use of Jacques Lacan's theory of the four discourses to interpret and unpack this phenomenon of the fragmented self. Lacan, in his seminar, The other side of psychoanalysis, introduced four types of discourses: that of the master, the university, the hysteric and the analyst (Lacan 1991).

The basic assumption that underlies Lacan's theory of the discourses is that communication is always a failure - that it has to be a failure - and this is the reason why we keep on talking (Verhaeghe 1995). On the basis of this assumption, Lacan developed an algebraic formula, empty of all content, to describe, analyse and interpret the discourses. This formula is a formal system, independent of any spoken word; what's more:

a discourse will determine the concrete speech act. This effect of determination is the reflection of the Lacanian basic assumption, namely that each discourse delineates fundamental relationships, resulting in a particular social bond.

(Verhaeghe 1995:95)

In these social bonds the subjects, as semblances (characters), play different roles according to the discourse in which they are situated. What is left are numerous narratives, each addressing a certain aspect of our lives.

The formula is made up of two parts, namely four positions which are fixed in relation to one another and four terms which can move between these four positions. Three of the four positions are derived from communication theory, while the fourth comes from psychoanalysis. Figure 1 depicts the basic understanding of communication, in which someone ('agent') says something to someone else ('other') to produce a certain effect ('product').

According to Verhaeghe (1995:96), the fourth position is, in fact, the first position, namely 'truth' (Figure 2). He goes on to state that Freud points out that ' $[w]$ hile we are speaking, we are driven by a truth unknown to ourselves', and, very importantly, that it is this truth that 'functions as motor and as starting point of each discourse'. In Aristotelian terminology, truth is the 'prime mover', driving the structure of discourse.

The ego (agent) does not speak. It is spoken. Freud termed this, as Verhaeghe (1999:96) points out, the 'third great narcissistic humiliation of humankind'. In this readjustment of the classical communication theory, it is not the subject who stands at the centre of the definition, but, rather, all importance goes to the signifier. Lacan defines the subject as the passive effect of the signifying chain. The subject as agent is only a fake agent, 'un semblant', a phony. The subject is only a role (character) that is played according to the law of the discourse in which it is participating.

Another affect of introducing this driving force of the discourse, is that the communicative sequence of the discourse is disrupted. According to classical communication theory, there is a direct relationship 


Agent $\rightarrow$ Other
$\downarrow$
Product

FIGURE 1

The basic communication model

\begin{tabular}{c}
\hline Agent $\rightarrow$ Other \\
Truth // Product \\
Source: Verhaeghe 1995 $\quad$ FIGURE 2 \\
The four position communication model
\end{tabular}

\begin{tabular}{|c|}
\hline Impossibility \\
Agent $\rightarrow$ Other \\
$\uparrow$ \\
Truth // Product \\
Inability \\
Source: Verhaeghe $1999 \quad \begin{array}{c}\text { FIGURE } 3 \\
\text { The disjunctions of impossibility and inability }\end{array}$
\end{tabular}

between the agent who translates a 'truth' and communicates it to the other and, in a feedback loop, it returns to the sender. This is not the case in the Lacanian discourse theory. Lacan refers to 'truth' as the half-speaking truth, because 'truth' can never completely be put into words; there is always a certain lack or absence between the 'truth' and the signifier communicating that 'truth'. This is also the reason we continue to speak, for if it was possible to verbalise the complete truth, everything would have already been said. Thus every discourse is open-ended and, because of this structural lack, it continues to turn and repeat itself.

The reason why communication is essentially impossible is that '[b]esides these four positions the formal structure of discourse consists of two disjunctions, expressing the disruption of the communicative line' (Verhaeghe 1999:97).

Verhaeghe (1999) interprets Lacan as follows:

the agent, who is only a make-believe agent, is driven by a desire which constitutes his truth; this truth cannot be completely verbalised, with the result that the agent cannot transmit his desire to the other; hence a perfect communication with words is logically impossible.

(Verhaeghe 1999:97)

Thus a disjunction of impossibility occurs (Figure 3), whereby the bridge between agent and other is always impossible to cross and thus the agent remains with an impossible desire. The four discourses will unite a group of subjects (social bond) through a particular impossibility of a particular desire. A disjunction of inability is also present, however, which concerns the link between product and 'truth' (Figure 3). 'The product, as a result of the discourse in the other, has nothing to do with the truth of the agent' (Verhaeghe 1999:97).

These two disjunctions represent a major Freudian notion the ever-present failure of the pleasure principle - and the consequences thereof. Verhaeghe (1999:98) expresses the consequences of this failure as the injunctions of inability, whose consequence is impossibility'. Man can never return to what Freud called 'primäre Befriedingungserlebnis'. He is unable to bring about this return, because of the primary Spaltung
- the division of the subject due to language (Freud 1950:317320). Nevertheless, humanity keeps on trying, and, in this, it experiences the impossibility. It is important to understand that this basic structure serves as a device to protect the subject, an idea to which I will later return in a discussion of the discourse of Genesis.

In the Lacanian discourse theory, the four positions are represented with four terms. These terms change positions, creating different discourses and, therefore, different socia bonds with different characters. The Lacanian terms originated in his earlier theory of the unconscious structured as language. Verhaeghe (1999:98-99) explains that Lacan's theory states that at least two signifiers $\left(\mathrm{S}_{1}\right.$ and $\left.\mathrm{S}_{2}\right)$ are needed in a basic linguistic structure. $S_{1}$ is the known as the 'master signifier', motivated by a desire to cover up a shortcoming, or 'absence', by pretending to be a 'guarantee'. The most powerful example of this master signifier is the ' $\mathrm{I}$ ', which affords an illusionary identity. $S_{2}$ (knowledge) is the term for the rest of the signifiers and signifying chains and refers to the knowledge contained within these chains. The next two terms are effects of the signifier. Once there are two signifiers, the necessary condition for the existence of a subject is fulfilled, as a signifier represents a subject for another signifier (1999:99). Therefore the third term is the divided subject (S) and the last term is the lost object, notated as object (a) - the object that the subject desires, but language cannot reach; it is a lost object as the result of the structural inability and impossibility of language, that is, the structural gap (//) between signifier and signified.

These terms within their fixed positions can be rotated over these four positions, resulting in four different discourses which can be expressed as a permutation of a four-term configuration, showing the relative positions of the decentred subject (S), the master signifier $\left(\mathrm{S}_{1}\right)$, knowledge $\left(\mathrm{S}_{2}\right)$ and object of desire, ' $\mathrm{a}$ ' (objet petit a). Such algebraic abstractions are very useful, because they are empty of specific content and can thus be utilised in the interpretation of various processes, social phenomena, systems and literary works. To this end, the rest of this paper will apply these four discourses to certain contemporary phenomena of the fragmented self in the transit hall of existence.

\section{INTRODUCTION}

\section{Why Facebook is so addictive! The virtual ' $m \mathrm{e}^{\prime}$}

The desire to be a unified ' $\mathrm{I}$ ' that can be communicated to others is a desire that drives all communication. Facebook provides an opportunity to communicate our 'selves' to an 'other', in a controlled environment. In this article, Facebook will be used as a metaphor of this desire to construct and control our 'self' that is communicated to others. The agent of the Facebook-self is the master signifier $\left(\mathrm{S}_{1}\right)$, the ' $\mathrm{I}$ ' that gives one the illusion of an identity on one's own and covers up the 'truth' of the divided (decentred) self (S) which lacks unity. The ' $\mathrm{I}$ ', as master signifier, filters the various other signifiers (bits of information) that are

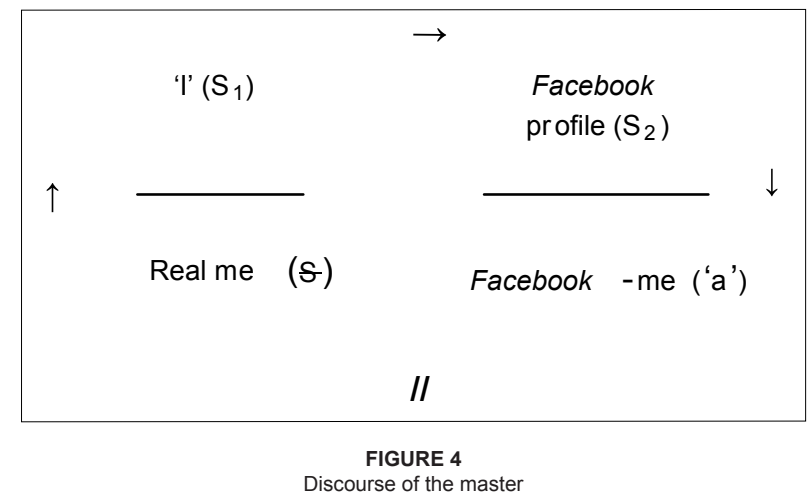


made available to the 'other' on Facebook. The 'I' controls the knowledge $\left(\mathrm{S}_{2}\right)$ to which others have access. This knowledge is created by various secondary signifiers $\left(\mathrm{S}_{2}\right)$, sustaining and upholding the master signifier. These signifiers and signifying chains combine to form the Facebook profile made up of information, wall postings, photos, music and so on. To rephrase: the Facebook-me is a persona people create to communicate themselves to others, the 'I' they want others to believe they are. Figure 4 transcribes this process into a Lacanian formula.

\section{Discourse of the master}

A typical master discourse is where the divided 'self' (S) is at the position of 'truth', the 'real me', unknown even to myself. The agent is the ' $\mathrm{I}$ ', the classical primary master signifier $\left(\mathrm{S}_{1}\right)$ who filters and communicates information/knowledge $\left(S_{2}\right)$ to the 'other'. This is the information (i.e. one's Facebook profile) given

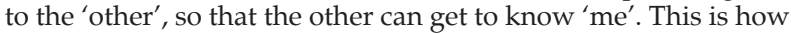
the 'other' is intended to see and understand (know) 'me'. The product of this discourse is (a) 'me'. The product is a 'me' that is communicated to my friends on Facebook, where this profile is meant to be the real 'me', but the truth of the matter is that it cannot be 'me'. This constructed product of the ' $\mathrm{I}$ ', the master signifier through knowledge of the profile $\left(\mathrm{S}_{2}\right)$, cannot be the 'true $\mathrm{me}^{\prime}$, because the 'true me' will continually elude the product of the profile constructed by the ' $\mathrm{I}$ '. There is an inability for the product and the 'truth' to be bridged, just as it is impossible for the 'me' (S) to be put into words and communicated to the 'other' through knowledge $\left(\mathrm{S}_{2}\right)$ about the 'me'.

This is the great attraction of Facebook: it offers a discourse where the master signifier $\mathrm{S}_{1}-\mathrm{I}^{\prime}$ ' - can control the 'me' that is communicated to the world. This is also the impossible desire that drives Facebook, because, in this virtual world, the impossible becomes possible and one can, from the comfort of one's PC, control the world's perception of one. On Facebook, one is the master of one's 'self' that is communicated through the control of information $\left(\mathrm{S}_{2}\right)$. On a primal level everyone desires this - to be in control of their own image, made up of various signifiers. One decides what photos are posted, what personal information is made available and what books you would like to have other people think you read, and so on. The problem is that it is only a 'virtual me' and those who know the 'me' in the 'real' world will compare their 'real' image of 'me' with my Facebook profile. The ' $\mathrm{I}$ ' is conscious or subconscious that this ' $\mathrm{me}^{\prime}$ (S) is divided (S) (i.e. fragmented) and that the 'profile $\mathrm{me}^{\prime}$ and the 'true $\mathrm{me}^{\prime}$ do not coincide. Nevertheless, this provides a unique opportunity to be the master of one's 'self' and, therefore, it is attractive and even addictive - because it is what humans desire: to be masters of their 'selves'.

This is only one possible interpretation of the discourse of Facebook; a discourse is like a text - the possible interpretations are endless within the limits of the root-metaphors (Ricoeur), within the limits of the free-play of signifiers $\left(S_{1}, S_{2}\right)$. This is applicable to all the interpretations of various discourses offered in this article.

\section{THE 'REAL' AS NON-VIRTUAL}

\section{The discourse of the fragmented self}

The focus will now turn towards the 'non-virtual me', the 'real me' beyond the master discourse of Facebook. What is the 'truth' of this 'real me'? This section will refer to Lacan's 'discourse of the hysteric', which is part of the original four discourses he identified, but this discourse will be placed into the context of the discourse of the capitalist, which he later developed.

The market as master signifier $\left(\mathrm{S}_{1}\right)$ is in the position of 'truth'. The market has become a 'global truth' that is unquestionable. This 'truth' has as its agent the decentred subject (S), who communicates itself to others through the expert knowledge of science and technology $\left(\mathrm{S}_{2}\right)$ in the production of objects for consumption (a). Interestingly, this discourse (Figure 5) is the

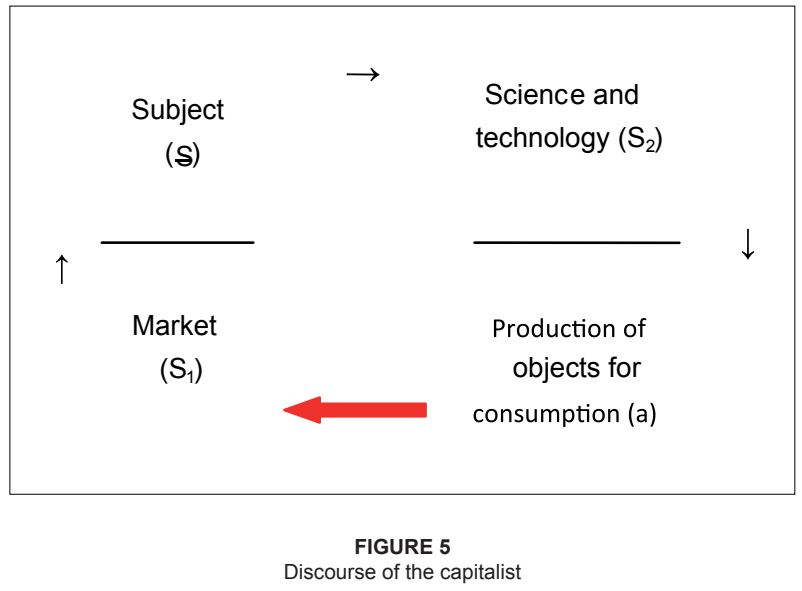

only discourse where there is an arrow between the position of 'production' and 'truth'. The market produces its own selfsustaining 'truth'. We can describe it as a dominant discourse, a grand narrative, but a hidden one, which underlies the other social discourses of the 'self'. The discourse of the capitalist provides the context for the other discourses. The subject is reduced to agent of the market in the production of objects, where '... every individual is really a proletarian' as Lacan formulated it (Declercq 2006:75).

This is not sustainable, as the subject would revolt against such position. Therefore, to sustain this dominant discourse (grand narrative) it needs to create social discourses that convince the subject of its own subjectivity and individuality as a free individual, who can freely choose from numerous possibilities and is thus not a slave or victim of the market. The 'free' subject also needs to be convinced that it is the market that provides it with this freedom of choice. An example of this can be found in the DSTV advertisement that states: 'Get used to choice!' The implication is: 'Get used to choice, because it is the gift the market offers you'. The market sets you free, presents you with choices and offers you the opportunity to choose your own individuality. What limits this apparent freedom of choice is that it needs to be within the parameters of production, because the production of objects of desire is the driving force of the market; production (a) feeds the market 'truth' $\left(\mathrm{S}_{1}\right)$ (Figure 6). Production floods the market with objects of desire so that the subject can choose and find its individuality therein.

\section{The discourse of the hysteric within capitalist discourse}

The only way the capitalist discourse can sustain itself, is if the 'truth' of this discourse - the master signifier $\left(\mathrm{S}_{1}\right)$, the market - is covered up ideologically and replaced with the objects of desire, which are the objects of production. The objects of production become the objects of desire, which convince the subject that it is essentially free to choose from these objects and, in that choice, the subject embraces its individuality.

The objects of desire become the 'truth' of the ideological discourse, which covers up the discourse of the capitalist. The 'truth' of the 'me'-subject who wants to function as a free agent and not as slave to the market, is, as Erich Fromm, has put it: 'I am what I have' (Fromm 1976). Herein lies the truth: that one is a slave to the market, but made to believe that one's 'freedom', one's 'truth', lies in the desired object.

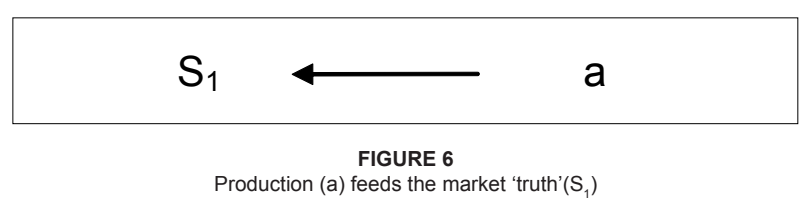


The subject, as Lacan points out, is no longer slave to the discourse of the capitalist, but enslaved to the objects of production (of choice) or, as he calls them: 'the objects of libidinal enjoyment' (Lacan 2001:415). This matches what has been described as the discourse of postmodern consumer capitalism driven by consumption - 'I am what I consume!' Frédéric Declercq asserts: '[o]ne of the main axes around which a capitalistically structured society revolves is libidinal enjoyment. Indeed, capitalist societies are about production and consumption of objects of libidinal enjoyment' (Declercq 2006:75). The 'self' (one's identity) is dependent on these objects: the car you drive, the clothes you wear, the neighbourhood in which you live and so on. They become the 'truth' of the subject. In Lacan's formula the object of desire (a) is in the position of 'truth'. One can infer that the driving force behind capitalist societies is captured in the advertising slogan: '[w]e must enjoy ourselves right here, right now' (Verhaeghe 1999).

Lacan insists that such a focus of the 'self' on the object of desire (of jouissance) does not possess the ability to sustain the 'self', because 'a subject, as such, doesn't have much to do with jouissance' (Lacan 1998:50). In fact, he later argues that it is exactly the lack of libidinal enjoyment that sustains this discourse (Lacan 2001:435). In The communist manifesto, Karl Marx argues that the production of surplus value (profit) is the primary driving force in capitalism, for the enjoyment of the capitalist at the expense of the proletariat. Today, surplus value is reinvested into the market and production becomes the driving force: '... we must produce to consume, but we must consume in order to be able to produce again' (Declercq 2006:80). The result is that nobody truly enjoys the surplus value (libidinal enjoyment) and therefore all consumers become proletariat (Lacan 1974).

This object of 'truth' is expressed in the 'self'. Yet, this object of truth, which is founded on the object of desire, never gives to the subject that which it promises: jouissance. It is logically impossible, as the object of desire is such because it can never be attained. So, even if the subject consumes (has) the desired object, it does not fulfil the desire and a new object must be found. The objects of libidinal enjoyment lose their impact as they proliferate; the moment everybody has the desired object, the ' $\mathrm{I}$ ' feels a loss of identity (individuality) and therefore it needs a new object of desire, which becomes its new 'true' identity. Once an object becomes available to everyone, it loses its worth and becomes a source of 'boredom rather than libidinal enjoyment' (Declercq 2006:79). The 'self' that is the agent of this object of desire, is continually changing. As a result, one is never 'one' with the desired object. Freud conceptualised this as being 'castrated' - cut off from the object of desire (surplus desire). As an example, imagine a new BMW X5 as the object of desire - one comes to possess it, to drive it and yet, somehow, it does not meet one's expectation - it does not provide jouissance. On the contrary, it leaves one empty; it does not generate the desired identity. Libidinal enjoyment is never attained, thus the subject continually has to find new objects which define it. Žižek calls this 'the explosion of the hysterical capitalist subjectivity that reproduces itself through permanent self-revolutionizing, through the integration of the excess into the "normal" functioning of the social link' (Žižek 2006). The 'excess' is the surplus production that is continually reinvested into the market to sustain/feed the capitalist discourse.

If the subject's 'truth' are objects of desire, then the subject is not connected to other subjects, but to these objects, resulting in loneliness, fragmentation and disconnection from the community. The promised libidinal enjoyment of the objects is intended to counterbalance this loneliness and disconnectedness however, it remains an empty promise, preventing the subject from interpreting itself as a victim of the market. Rather, it encourages the subject to see itself as a victim of failed promises, which is its own fault resulting from a wrong choice of object and it continues to hope the next choice will be more successful.

The object of desire/production cannot give one one's identity. Declercq, referring to Lacan, explains this within the context of sexual relationships. The sexual act cannot generate a signifier or identitiy. In other words, the relation with the libidinal object of enjoyment cannot give the subject its identity, only love can (Declercq 2006:76). However within this discourse the subject's relation to others is always via the object.

This divided (fragmented) 'self' hopes that the 'other' does not see the fragmentation, but rather the subject in possession of the object of desire. In other words, the master signifier that defines the subject is held in the position of the 'other'. What is important is how the ' $\mathrm{I}$ ' is perceived by the 'other'. Thus, the Jones' have become the master signifier $\left(\mathrm{S}_{1}\right)$. The ' $\mathrm{I}$ ' as master signifier, is captive to the view the 'other' has of one. The objects of desire (educational degrees, car, cell-phone, clothes, beautiful wife) communicate who ' $\mathrm{I}$ ' am to the 'other', but, in reality, I cannot control what they perceive. The master signifier is with 'others', 'others' define the ' $\mathrm{I}$ ' and therefore it is the 'other' the ' $\mathrm{I}$ ' tries to please.

In this context Freud speaks of the 'Ego-Ideal'. The Ego-Ideal stands for what the person wants to be (Declercq 2006:76). The subject needs the ideals and signifiers of another, it needs to be identified through the 'other'. Lacan claims that the Ego-Ideal is the 'eye' through which the subject sees itself. The subject needs to appear loveable to 'others' and then, and only then, to itself (Lacan 1998:256-257). However, the 'other's' perception, the product of communication, is a certain knowledge $\left(\mathrm{S}_{2}\right)$ of the subject that has little relevance to the 'truth' (object of desire), which the subject wants to communicate; therefore, the subject continues to ask from the 'other': 'What must I have to be someone in your eyes?' Lacan calls this the 'discourse of the hysteric'. Figure 7 depicts this discourse as configured to Lacan's formula.

\section{THE 'REAL': A DISCOURSE OF THE HYSTERIC}

According to Wajcman, the discourse of the hysteric is the most fundamental primary discourse, 'because it discloses the structure of speech in general and, second, because it sheds light on dimensions of human discursive practice ...' (Wajcman 2003). One could speak of normal hysteria as characteristic of any speech act.

Normal hysteria has no symptoms and is an essential characteristic of the speaking subject. Rather than a particular speech relation, the discourse of the hysteric exhibits the most elementary mode of speech. Drastically put: the speaking subject is hysterical as such.

(Wajcman 2003)

The 'other' is constituted as capital, 'Other', the hysteric commands the 'Other' (Tell me who I am) from the position of 'agent' and thus totally surrenders to the 'Other' to whom the hysteric gives the power to answer: Tell me! Answer me! And whatever you say, that is what I am! This demand compels speech, because it solicits an answer, as Wojcman states, 'as if all of language carried the mute question: "Who am I?"' (Wajcman 2003). This fundamental question arises from the structure of speech itself and the synchrony of a question and answer: Tell me who I am? < --- > I am who you say. This discourse reveals the subject's symbolic dependence on the 'Other', 'that all speech proceeds from the place of the Other ... [it] is master, letting the as yet inarticulate subject come into being: I am / who you say $<--->$ I say / who you are' (Wajcman 2003). In the hysteric's discourse it is as if the subject (S) commanded the Other, yet, symbolically, the hysteric is entirely dependent on the 'Other' for being the master signifier that transforms it into a subject. The question: 'Who am I?' receives an answer: 'You are who I say!' This inarticulated question on the side of the 'Other' ends with the gift of speech, but a gift with an essential flaw. By responding to the fragmented (S) subject's question: 'Who am I?', the Other lets the subject come into being. The answer, which needs to be necessarily specific, reduces the subject's quest to a finite object: You are this object! The question, 'Who am I?' receives an answer, 


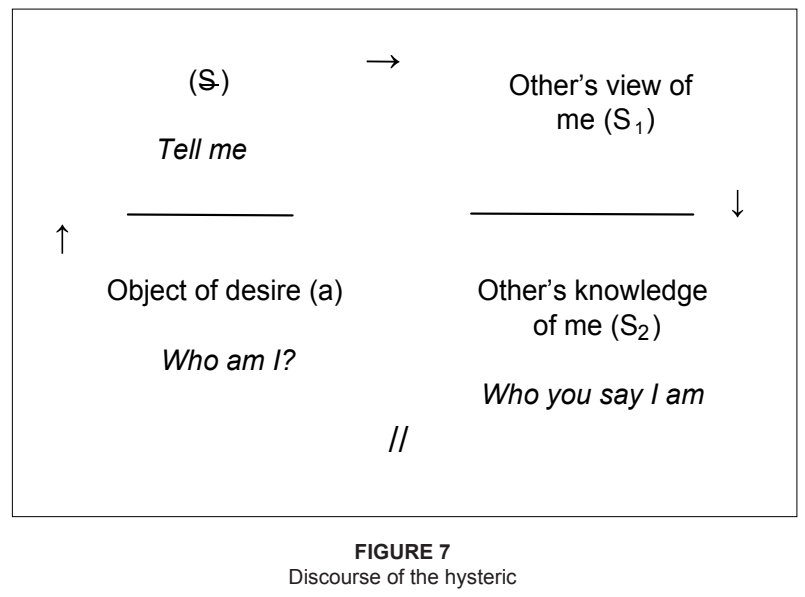

calls a subject into being as a 'what you are' and thus objectifies the subject. The division of subject and object is an irrevocable effect of language and provides the foundation for continuous speaking. The answer $\left(\mathrm{S}_{1}\right)$ is employed to produce and interpret an endless play of numerous signifiers which cannot bridge the gap between subject and object, resulting in the endless play of language. Between the signifier/s and the signified there is différance (difference and deferment, Derrida 1978) and thus the chain of signifiers $\left(\mathrm{S}_{2}\right)$ can never be conclusive.

Lacan called this the discourse of the hysteric, not because of any medical or psychological definition of hysteria, but because there is no conclusive answer to the question: 'What is hysteria?' So, just as the medical-psychological phenomenon of hysteria generates endless theory (knowledge), this discourse produces endless knowledge $\left(\mathrm{S}_{2}\right)$. According to Wajcman, hysteria has three basic aspects, (1) an answer is requested, which creates knowledge, (2) knowledge responds the symptom defining the hysteric and (3) all answers 'fail to master their object, none can silence the hysteric' (Wajcman 2003) - nothing satisfies the desire of the fragmented 'self'. No one and nothing can satisfy the fragmented 'self's' desire.

Freud believed hysteria to be the nucleus of all neurotic disorders and Lacan has shown the speaking subject to be fundamentally hysterical. It is thus no longer sufficient to conceive of hysteria as a fact of language among others; it is only a fact of language because whoever speaks is hysterical (Wajcman 2003).

We can go further and say that the subject demands to be recognized as a fact of language (see the formula 'Tell me who I am <--- > I am what you say'). The hysteric not only requests that language be used as a means for explaining her; she also insists on being acknowledged as a being of speech.

(Wajcman 2003)

This may explain why the hysteric discourse is the 'real'. The 'real self' is a decentred, debarred, fragmented 'self' and, as such, is an unavoidable fact of the structure of language. This 'real self' has been hidden from humanity in Western history by different discourses, mainly the religious discourse of divine authority and the discourse of modernity. It is only now that the 'self' experiences itself as fragmented, as a result of the different roles it has to play in the relativity of the various language games (narratives) in which it finds itself. The transit hall of experience reveals this 'real self' in a concrete way.

\section{IN RESPONSE TO THE 'REAL': MASTER AND UNIVERSITY DISCOURSES}

The discourse of the hysteric is unbearable and humanity seeks to escape the 'real' by fleeing, either to the discourse of the master, or the discourse of the university.

\section{Facebook as master discourse in response to the 'real'}

It seems as if the only way out of this endless chain of signifiers (knowledge), is to become the master signifier oneself - as in Facebook, where one creates one's own social bonds and is no longer connected only to the object of production/desire. Facebook turns the question around: from 'Tell me who I am', to 'I'll tell you who I am'. Facebook as a discourse, is a signifying chain $\left(\mathrm{S}_{2}\right)$, a response to the question of the other: 'Tell me who you are'. It is a question that is not asked by someone specific, but by an anonymous 'other' out of the deep void of the World Wide Web. The master signifier $\left(\mathrm{S}_{1}\right)^{\prime} \mathrm{I} \mathrm{I}^{\prime}$, responds by creating and subordinating the knowledge $\left(\mathrm{S}_{2}\right)$, the secondary signifiers, into a chain that says: 'This is who I am'. The product is a virtual, constructed ideal image, an ideal ego that the master (signifier) controls. The master's discourse is the exact inverse of the hysteric's discourse, and therefore can easily be perceived as the redemptive alternative to the 'real' of hysteria.

Yet, the master discourse of Facebook is structurally flawed: the knowledge (information) about my 'self' is filtered through the ' $\mathrm{I}$ ' (master signifier) and is always only 'half the truth'. The master signifier constructs a unity (totality) by denying difference; the subject is consciously, or subconsciously aware, that the constructed image (profile) is virtual and not real. It is constructed by excluding difference, thus the subject lives in fear of this 'real', the excluded difference, which continually threatens to deconstruct the virtual image. The unbridgeable gap between object and 'true subject', is the unbridgeable and unavoidable gap between virtual image and fragmented 'self'. The conclusion, therefore, is that Facebook is an illusionary, redemptive alternative to hysterical 'real'.

\section{The discourse of the university/modernity and the remnants thereof}

The discourse of the university (Figure 8 ) can be described by what Heidegger coined 'onto-theology' (Heidegger 1969), or what Levinas' (Levinas 1969) idea of reducing the other to the same and thereby seeking to eliminate difference. The position of 'truth' is filled, in the university discourse, by the master signifier $\left(\mathrm{S}_{1}\right)$ as a single, 'fundamental truth', the 'one truth' to which everything can be reduced. The position of 'truth' is filled, in the university discourse, by the master signifier (S1) as a single, 'fundament truth', the 'one truth' to which everything can be reduced, 'making appear natural or conventional what is in fact a forced and artificial construction of reality' (http:// www.nosubject.com).

This 'one truth' manifests as the dogmatic 'truths' of religious or scientific fundamentalism; or less aggressively as specific paradigms or theories for organising knowledge (signifier chains) into systems of totality. The master signifier $\left(\mathrm{S}_{1}\right)$, the 'one founding truth', expresses itself through its agent, namely systems of knowledge as chains of signifiers $\left(\mathrm{S}_{2}\right)$, all sustaining and referring to this 'one truth' $\left(\mathrm{S}_{1}\right)$. The chain of signifiers is the theories, moral values, way of life, methodologies and so forth. This 'truth' $\left(\mathrm{S}_{1}\right)$ addresses itself and is communicated through the chain of signifiers $\left(\mathrm{S}_{2}\right)$, as its agent, to the 'other'. The position of 'other' in this discourse is filled with the potential convertee, the object or the 'other' which is addressed by the theory/system of knowledge $\left(\mathrm{S}_{2}\right)$ with the desire to include this object/'other' into the totality of the master signifier $\left(\mathrm{S}_{1}\right)$. The 'other' is the object that needs to be begriffen (understood), ergriffen (taken) as a begriff (idea) so as to re-establish the master signifier as master. The object is the 'other', not yet included in the totality and that needs to be incorporated before it threatens the totality based on the 'truth'. This might explain why fundamentalism, in all its different forms, tends to be so aggressive and filled with a sense of urgency. 


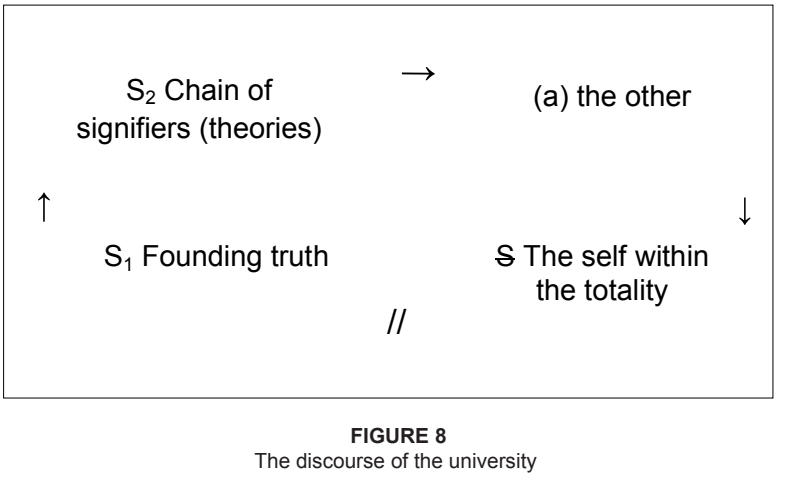

The product of this discourse is the 'self', understood within the signifying chains $\left(\mathrm{S}_{2}\right)$ of the totality $\left(\mathrm{S}_{1}\right)$, namely a 'self' that has been converted and thus identifies with the totality $\left(\mathrm{S}_{1}\right)$ 'I am a right wing evangelical', 'I am a positivist empiricist', or 'I am an INTP'. The result is a subject that is definable. The problem is that there is always a difference or différance, as Derrida $^{1}$ (1978) termed it, which eludes and thus questions this definition, threatening to deconstruct it, making the production of knowledge never-ending, continuously trying to reduce the 'other' to the same.

Just as the Facebook discourse could be addictive, so is the discourse of the university, which manifests itself in the popularity of various events, such as men's camps and various other therapeutic theories, based on a certain 'truth' and all designed to help one find one's 'true self'. Yet this 'true self' is only a constructed product of a discourse sequence which began with a certain master signifier. Is there redemption for this fragmented decentred 'self'? The redemption that Lacan offers is the redemption of the discourse of the analyst.

\section{THE DISCOURSE OF THE ANALYST}

\section{Characteristics}

Some defining characteristics of analyst's discourse (Figure 9) will be highlighted in this section. Interestingly, the analyst does not take the position of the agent of the discourse, as would be the case in most psychological therapeutic models, but is positioned outside the discourse. Only the desire of the analyst directs the discourse and thus the object of desire (a) is at the position of the agent.

The desire of the analyst is, according to Lacan, the desire to establish and keep an opposition between demand and desire. Demand is desire that exists under the illusion that desire can be fulfilled. Pure desire is conscious that the object of desire can never be fulfilled; it becomes desire for pure difference. At the end of the analysis it is the desire of knowledge that is very different to the horror of knowledge. The difference between the 'desire of knowledge' and 'the horror of knowledge' is that the desire of knowledge is the desire of pure difference différance (knowledge of the structural and logical inability and impossibility of language), the deferment between signifier and signified. The horror of knowledge, on the other hand, is knowledge in the discourse of the university, where knowledge assumes the position of agent, subordinating differences into a totality. The 'truth' of the desire of the analyst is knowledge of différance. Thus the position of 'truth' is filled with knowledge $\left(\mathrm{S}_{2}\right)$.

Jacques-Alain Miller (2004) argues that it is not the desire of knowledge of the analyst, but the analysand. Knowledge $\left(\mathrm{S}_{2}\right)$ is at the subconscious level at the position of 'truth'; it is both the knowledge the analysand believes the analyst has, as well as the unconscious knowledge of the analysand. The desire of

1.'The economy of this writing is a regulated relationship between that which exceeds and the exceeded totality: the différance of the absolute excess' (Derrida 1978). the analyst, which is the desire of knowledge of the analysand, is directed towards the decentred (debarred) subject in the position of 'other' (S). This desire for pure difference allows the discourse to follow three steps:

- Firstly, it allows pure difference to introduce and produce a new signifier one $\left(S_{1}\right)$, which divides the subject and puts deconstructive tension on knowledge.

- Secondly, it orientates the subject towards the 'real'.

- Thirdly, it facilitates the appearance of the desire of the analyst in the analysand.

To make this pass possible, Horne (2004) points out that it is necessary 'to distinguish the lack-of-being, which alienated the subject to the symbolic, the symbolic must have arrived at a point of impossibility'. The pass to the analytic implies that the object becomes 'truly real' to the subject because it is not a semblance anymore. As a result, the desire of the analyst is for the difference between the truly 'real' and the semblance to reveal itself, but this desire is not for the 'real', but by the 'real'. This aspiration by the 'real' is a passage from having a symptom, to becoming a symptom: a decentred 'self'.

By introducing a new signifier one $\left(S_{1}\right)$ in place of the old master signifier - so that the subject can recognise the linguistic structural inability which is the reason for desire and also the impossibility of desire - already satisfies the desire. This, Verhaeghe (1999:103) argues happens through a passage to the primal fantasy and the realisation of the impossibility thereof.

In the discourse of the analyst (Figure 9):

the revolutionary agent-a-addresses the subject from the position of knowledge that occupies the place of truth (i.e., which intervenes at the 'symptomal torsion' of the subject's constellation), and the goal is to isolate, get rid of, the master signifier that structured the subject's (ideologico-political) unconscious.

(Žižek 2006)

I would add: and replace it with a new signifier one, based on the 'truth' of the knowledge of différance.

Lacan's algebraic formulas are empty of content so that they can be used to analyse social phenomena. These formulas have been used differently to reach various conclusions, for example, Miller observes that our civilisation today fits the formula of the analyst's discourse (Miller 2004). This paper argues, rather, that the discourse of the hysteric fits our civilisation today. In regard to this, Žižek (2006) argues:

the agent of the social link is today a, surplus enjoyment, the superego injunction to enjoy that permeates our discourse; this injunction addresses $\mathcal{S}$ (the divided subject) who is put to work in order to live up to this injunction. The truth of this social link is $S_{2}$, scientific-expert knowledge in its different guises, and the goal is to generate $S_{1}$, the self-mastery of the subject, that is, to enable the subject to cope with the stress of the call to enjoyment (through self-help manuals, etc.).

(Žižek 2006)

Miller (2004) defends his synthesis of civilisation and psychoanalytic link by arguing that in our civilisation the four terms are kept apart and isolated, as each operates on its own,

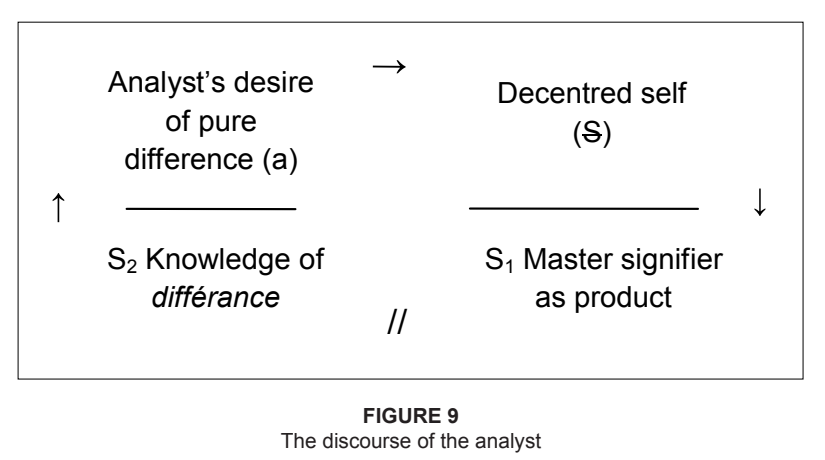


while in psychoanalysis they are brought together into a coherent link. Agamben (2004) disagrees with Miller, maintaining, rather, that the task is not synthesis, but separation and distinction, referring to Benjamin's (1986) link between law and violence. Agamben argues that the two need to be separated so that right does not become might, nor might become right. These ideas will be picked up in the following section. It would be a misuse of the Lacanian formulas to develop a 'correct' interpretation of phenomena. The desire that drives the use of these formulas is the desire of pure difference and thus different interpretations are a logical consequence.

\section{THE BIBLE AND THE DISCOURSE OF THE}

\section{ANALYST}

\section{Deconstructive dialogue}

Can one bring the Christian narrative into dialogue with Lacan's thoughts? Lacan himself made use of thoughts from Saint Paul (Sharpe 2006), but this article will attempt such a dialogue by re-reading the Genesis story in the light of Lacanian algebraic formulas. Genesis is the story, amongst others, of the creation of humankind. Before reflecting on this, though, it is necessary to first turn to Lacan's understanding of the birth of the 'self'.

For Lacan, the 'self' is essentially a speaking being (Sharpe 2006), even though a human being is not born with speech; language only comes at a later stage in the child's development. The development from human being (biological entity) to subject (speaking being) is the result of the development of language. Language develops as the result of the resolution of the oedipal complex, through what he terms 'castration'. The child devotes itself to fathom what it is the mother desires, in an effort to make itself a desirable (phallic) object for the mother - a fully satisfying love-object. This can be described as the child's attempt to bridge the difference, or the lack (absence) of unity, which is the consequence of birth. It is an attempt to heal the experience of oneself as a separated decentred entity. According to Lacan, the father will intervene in a way that thwarts this oedipal aspiration. In this Lacanian interpretation, the father is a figure of the law. This body of nomoi is what he calls the 'big Other' of the child's given sociolinguistic community, of which the 'father' becomes a 'spokesperson' or, we could say, its 'figure'. Lacan call this law 'the name (nom) of the father, trading on a felicitous homonym in French between nom (name) and non (no)' (Sharpe 2006). The father's 'no' becomes a figure of the laws, conventions and signifiers of the language community that the child and the mother are part of, thus ordering and giving meaning to that world as something separate from the 'self'.

Language belongs essentially to the community (the big Other). The child learns to identify itself with and within this symbolic order of language. The human being, according to Lacan is a 'decentred speaking animal' whose desire comes to be mixed with the imperatives stipulated within the natural language of its society.

As a 'castrated animal', the human is forced to pursue its desire on 'the inverted ladder of the signifier', within the phallic order of its society's 'big Other'. It is only once 'castrated' - having accepted the unconditional authority of a body of convention that the subject can interpret and perceive the world as a set of discrete identifiable objects. This body of convention is ordered into a totality by the master signifier, which is a signifier that the subject most deeply identifies with, and thus they play a key role in giving meaning to the world. Master signifiers orient the subject vis-à-vis all the other signifiers which structure its sense of itself and the world. The master signifiers are empty signifiers without signifieds. It is important that they are empty because the concept, or referent of any master signifier, will always be something impossible for any one individual to comprehend, thus binding the individual to the 'Other'. So, although there is a gap between the signifier and what is signified, the subject takes comfort in the belief that someone (the 'Other') knows. As desire is through the 'Other', so belief is always through the 'Other'. Lacan sees it as part of the function of 'castration', which subjects are debarred from knowing what the master signifiers signify. His argument is 'that it is this lost 'signified,' which would as it were be 'more real' than the other things that the subject can readily signify, that is what is primordially repressed when the subject accedes to becoming a speaking subject at castration' (Sharpe 2006).

A primal fantasy is created to help the subject cope with this apparent 'loss of the signified'. Sharpe (2006) interprets Lacan as follows:

The primal fantasy represents what occurred at castration in the terms of a narrative of possession and loss. This fantasm thus consoles the subject by positing that s/he at one point did have the phallic Thing, but that then at castration, it was taken from the subject...

(Sharpe 2006)

The 'truth' of the 'castration' (the 'no' of the father) is that it prohibits what was not possible in the first place - the separation (difference) cannot be bridged.

An interpretation of the Creation story in Genesis ${ }^{2}$ story will follow, placed within the matrix of Lacan's interpretation of the birth of the decentred, debarred subject.

There are certain defining, significant moments within this story. The pre-fall moment describes a 'reality of harmony' between creator and creation with the pronouncement by the creator that all is 'good'. This so-called 'good and harmonious' co-existence between Creator and creation does not seem to be unanimous, as the creation is experiencing a lack, a difference, an absence of unity, and is easily tempted by a desire to be more like the Creator and bridge this difference. Creation (Adam and Eve) is driven by this difference (absence of unity), as they perceive themselves less than the Creator; the 'creation' perceives itself different it lacks this perfect unity with the Creator. Through the cunning of the serpent this unconscious/unexpressed desire is awoken in Eve, she perceives this difference between herself and the Creator and consequently desires to be more like the Creator. This desire to bridge the difference is objectified in the 'fruit of the tree of the knowledge of good and evil'. This 'fruit', as object of desire (a), will be in the position of the agent - that which would lead creation towards unity with the Creator. The 'gift' of the fruit is 'knowledge of good and evil' $\left(\mathrm{S}_{2}\right)$ which imparts the ability to classify what is 'other' as either 'good' or 'evil' thus giving the subject mastery $\left(\mathrm{S}_{1}\right)$ over 'others' (creation). This mastery through 'knowledge of good and evil' is believed to bridge the difference between creation and Creator; with this knowledge creation can also pronounce judgement, similar to the Creator who speaks, creates and pronounces things as 'good'.

Only after eating the fruit, do Adam and Eve realise that it has not brought about the desired effect, but only reveals them as naked, separated and decentred in relationship to each other. To be 'naked' is the natural, true, real state of humanity.

The Genesis story is thus not a primal fantasy story, or a master discourse of the loss of the signified, but a revelation of the 'real' - the decentred, 'naked self'. Yet, the consequence

2.Genesis 3 , the Fall of man, reads as follows: ${ }^{1}$ Now the serpent was more crafty than any of the wild animals the LORD God had made. He said to the woman, 'Did God really say, "You must not eat from any tree in the garden?"' ${ }^{2}$ The woman said to the serpent, "We may eat fruit from the trees in the garden, 3but God did say, "You must not eat fruit from the tree that is in the middle of the garden, and you must not touch it, or you will die." " 4'You will not surely die', the serpent said to the wou must not touch it, or you wis. knows that when you sat of knowing good and evil.' "When the woman saw that the fruit of the tree was good for food and pleasing to the eye, and also desirable for gaining wisdom, she took some and ate it. She also gave some to her husband, who was with her, and he ate it. ${ }^{7}$ Then the eyes of both of them were opened, and they realized they were naked; so they sewed fig leaves together and made coverings for themselves. ${ }^{8}$ Then the man and his wife heard the sound of the LORD God as he was walking in the garden in the cool of the day, and they hid from the LORD God among the trees of the garden. 'But the LORD God called to the man, 'Where are you?' ${ }^{10} \mathrm{He}$ answered, 'I heard you in the garden, and I was afraid because I was naked; so I hid.' 11 And he said, you in the garden, and I was afraid because I was naked, so I hid." "And he said, 'Who told you that I commanded you not to eat from?' "The man said, 'The woman you put here with me--she gave me some fruit from the tree, and I ate it.' 'Then the LORD God said to the woman, 'What is this you have done?' The woman said, 'The serpent deceived me, and I ate.' 
of this disobedience, of the desire to eat the fruit is 'castration' (separation): they are expelled from paradise.

The lost signified is 'paradise', thus one could interpret Genesis as a primal fantasy story of the loss of paradise, and the primal belief that somewhere, someone has the secret how to return to paradise. This has certainly been a dominant interpretation of religion in the offering of clues in how to regain the lost signified (paradise).

This paper offers an alternative interpretation (Figure 10): Genesis 3 is a narrative attempt to reveal to humanity its 'true' state, the 'real'. To be banned from paradise is not a form of castration, but an essential truth that, between Creator and creation, as well as between creation singular (Adam) and creation plural others / Eve, there needs to be separation otherwise the subject as an ' $\mathrm{I}$ ' cannot be. This inability and impossibility (castration or barring of the 'self'), spoken of earlier is there to protect the 'self' from self-destruction. The story also conveys that ' $\mathrm{I}$ ', the primary master signifier $\left(\mathrm{S}_{1}\right)$, is 'naked', exposed and fully aware ${ }^{3}$ of its separation from the 'other' and 'Other', thus revealing the truth of the lacking and desiring subject (S) as a 'naked I'; for the first time in all these discourses does $S_{1}$, as product of the discourse, directly refer and reveal the truth of the discourse and, as such, they coincide.

This is paralleled only in the discourse of the capitalist (Figure 5), where the product (a) production coincides with the truth of capitalism, namely production. Thus, these two are truly grand discourses as impossibility and the inability become able and possible. One discourse reveals the subject as agent (slave) of the market, the other reveals the subject as a naked decentred 'self'. Two 'truths', yet, in one discourse, the 'self' is a slave objectified by the master (market), and in the other the 'self' is liberated to embrace its symptom, become its symptom - a naked 'self', which is its 'truth'.

\section{A JOHANNINE CHRISTIAN DISCOURSE}

\section{The discourse of Genesis and the discourse of the analyst}

The discourse of Genesis provides the 'self' with a narrative of the real, namely the 'self' as naked, vulnerable, decentred, debarred and fragmented. The fragmented 'self' in the transit hall of existence does not embrace its naked fragmentedness as its 'truth', but believes it to be merely a symptom that can be healed. Thus it continually seeks redemption in the discourse of the hysteric, the discourse of the master, or the discourse of the university. This which leads to increasing fragmentation, a never-ending search for different answers (objects of desire) to an unanswerable question (insatiable desire), trying on all these different clothes (characters) of the different narratives (discourses) of which it is a part, all in an attempt to heal the symptom by trying to cover up the essential, naked 'self'.

This paper attempts to utilise Genesis 3 as a primal fantasy, not of the lost signified, but of the 'real', the naked (pure) difference: difference, responding to the discourse of Genesis with a redemptive Christian discourse that does not seek to escape the nakedness or heal the symptom, but embrace and become the symptom: to be naked. The framework I employ is the Lacanian discourse of the analyst as the formula for a redemptive Christian discourse. Mainly Johannine imagery and metaphors have been used, because the Gospel of John was written as a discourse that created the social bond of the Johannine community as a redemptive alternative to the other communities, or other discourses of social bond.

Christ is not the agent of this discourse, as the analyst is not the agent of the discourse of the analyst. The agent of this discourse is the desire for pure difference, that which embraces pure difference without destroying it. Only true love, as Christ

3.They became aware of their nakedness and were embarrassed and hid themselves.

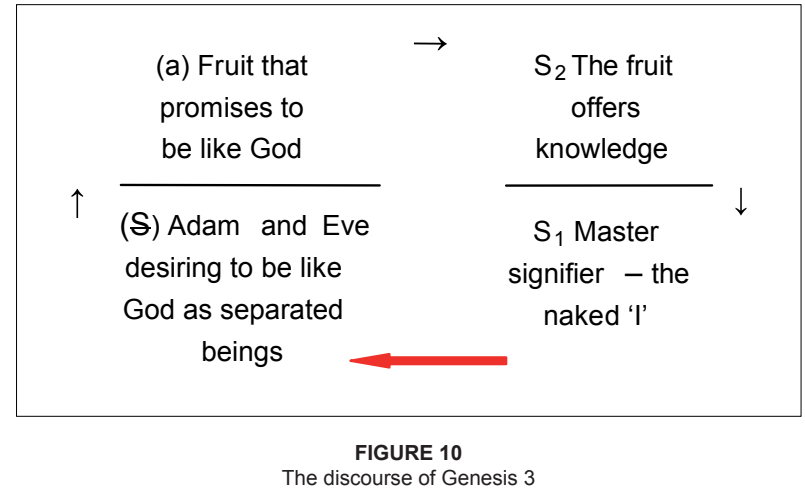

revealed it - love of enemies (love of the 'other' as 'other') can embrace difference. Only the unconditionality of grace which demands nothing in return, can embrace difference without including it in the same. Thus, love and grace are the agents of this discourse that takes the 'real' of Genesis seriously, without attempting to escape, heal or divert from this 'real'. Love and grace are also the desires of Christ, the new commandment, the new agency, he revealed to the world. The agent of this discourse is grace alone, revealed in love of the 'other' as 'other'. Yet, love and grace are also the desires of the subject, the subject's need to be loved - not just loved because one has the 'phallic Thing', but loved unconditionally, thus the desire for grace - to be loved without first fulfilling some laws, but to be loved out of grace.

What 'truth' drives this desire? This 'truth' is the 'truth' revealed in Genesis, the knowledge of pure, naked difference: différance. So, in the position of 'truth' one can place the knowledge of différance. In the Gospel of John, Christ describes himself as 'the truth, the way and the life' (John 14). His interpretation of himself as 'truth' is not the 'truth' of a master signifier, but as a servant signifier signifying a way of living, knowledge of how to live. What content does Christ give? He commands those who want to follow in this way of life to love; he assures them that by loving they will be identified as those belonging to this way of life. What kind of love is this? Christ answers and says: '[n]o greater love can anyone have than to lay down his life for another'.

I would like to give this laying down of one's life a Derridian interpretation as 'radical hospitality'. Radical hospitality is to open yourself toward the 'other' to such an extent that the 'self' is destroyed/deconstructed. To truly offer hospitality to the 'other', you allow the 'other' to become host and yourself hostage in your own home (Derrida 2000). This is not merely the knowledge of pure difference, but it is the 'truth' of the knowledge of pure naked difference: différance (the 'other' that is not the same), which is acknowledged and loved, without the horror of reducing it to the same and without offering halfhearted hospitality under the laws of the same (the home). This deconstructs (destroys) the 'self', exposing it as naked and vulnerable; that is the 'truth' of the knowledge of difference.

Love and grace, as agents of the 'truth', are communicated to the 'other', the debarred 'self' (S), struggling to cope with its symptom. In the light of love and grace, the 'self' realises that it does not need the 'phallic Thing' of desire to be loved and accepted. Love and grace, therefore, deconstruct the demand (law) of all the phallic signifiers $\left(\mathrm{S}_{1}\right)$ that have enslaved the 'self' in the master discourse; deconstruct the hysterical desire for ever more knowledge $\left(\mathrm{S}_{2}\right)$ of the 'self'; and deconstruct the discourse of the university's need to reduce the 'other' to the same (a). This crucifixion (deconstruction) of the demands (laws) that drive these discourses releases the 'self', liberates the 'self', to recognise itself in the light of love and grace and the product of this love and grace is a new identity $\left(S_{1}\right)$. It is not a master signifier, but a servant signifier, an ' $\mathrm{I}$ ' that embraces (loves) and becomes its symptom (naked) as it realises that, in the eyes of the 'other', they are loved without any signifiers: as naked. 


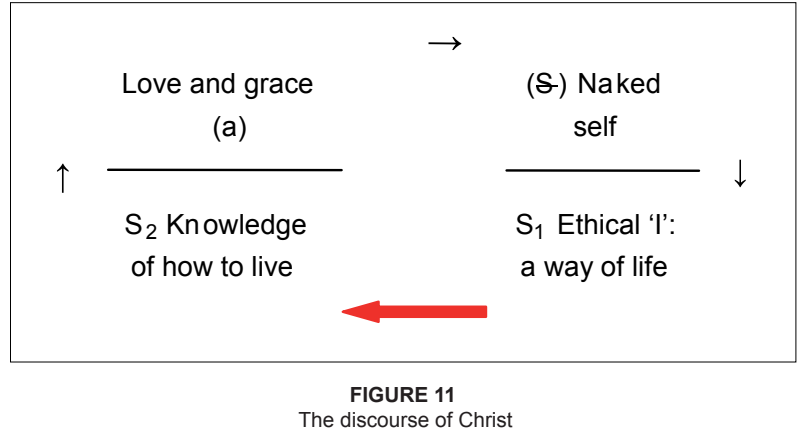

The new master signifier $\left(\mathrm{S}_{1}\right)$, the product of the Christ discourse (Figure 11), is an ' $\mathrm{I}$ ', a 'self' that has become its symptom (naked). It has become a naked ' $\mathrm{I}$ ' through the agents of love and grace revealed through the eyes of the 'other' and which has crucified (deconstructed) the laws (demands) of the various discourses. This naked 'self' realises its dependence on the love of the 'other' for its identity, but no longer as a demand (Tell me who I am), but as a product of love. The relation to the 'other' is no longer the relation of the hysteric to the 'other', but as one who understands itself in relation of love to the 'other', who is naked as well, wounded, vulnerable, exposed, fragmented and, therefore, the 'self' discovers itself as neighbour to the other naked selves. ${ }^{4}$ Levinas (1969) points out that ethics (responsibility towards the 'other') becomes the master signifier $\left(\mathrm{S}_{1}\right)$, the first philosophy, as the 'self' sees itself as naked in the naked eyes of the 'other' and thus realises its dependence on the love of the naked 'other', but simultaneously as one responsible to love the 'other' and so this Christ discourse (Figure 11) creates the social bond of a new community of naked 'selves'. It is a discourse that, through grace and love, deconstructs the demands and the desires of the various discourses and reveals a 'self' that does not have the symptom of fragmentation, but is fragmented - a naked 'self' amongst other naked 'selves' co-dependent on love for their 'truth'.

$\mathrm{S}_{1}$, the master signifier as the loved, naked 'self' in responsibility toward the 'naked other', is the product of this discourse which directly relates to the 'truth' of this discourse $\left(S_{2}\right)$ - knowledge of pure difference is knowledge of the 'naked self'. This discourse creates a social bond, a redemptive community, of 'naked selves' in responsible for each other, not a community that seeks to regain the lost signifier of paradise, but that embraces, becomes and redeems the naked, fragmented 'real'.

\section{CONCLUSION}

\section{Holistic pastoral redemptive community}

I have described holistic pastoral redemptive communities elsewhere (Meylahn 2010:195ff) as communities embedded in the story (discourse) of Christ and, as such, they could offer the fragmented 'self' in the transit hall of existence a redemptive alternative, for the discourse of Christ is holistic in its response to the other discourses, but more essentially, because it is the discourse of the 'real'.

The discourse of Christ is pastoral, as it takes the real desires seriously, without the protection of phallic signifiers. It is also redemptive, in that it heals the self from its fragmented symptom by helping it to embrace and become the symptom, as well as messianic, in that it longs for a community of naked selves who no longer elude themselves. Such a community will be made possible by the agents of love and grace deconstructing the demands and signifiers, creating a space for the real which is still to come.

This interpretation of the discourse of Christ should not be interpreted as a new master signifier, but as a wounded, naked

4.I have written about this ethical dependence on the Other in which the self is created as self in responsibile love toward the other in a previous article (Meylahn 2009). interpretation, offering the clothes of love and responsibility to a wounded, fragmented and naked world.

\section{REFERENCES}

Agamben, G., 2004, The state of exception, University of Chicago Press, Chicago.

Benjamin, W., 1986, 'Critique of violence', in P. Demetz (ed.), Reflections: Essays, aphorisms, autobiographical writings, trans. E. Jephcott, pp. 277-301, Schocken, New York.

Declercq, F., 2006, 'Lacan on the capitalist discourse: Its consequences for libidinal enjoyment and social bonds', Psychoanalysis, Culture \& Society 11, 74-83.

Derrida, J., 1978, 'Cogito and the history of madness', in J. Derrida (ed.), Writing and Difference, transl. A. Bass, pp. 36-76, Routledge, New York.

Derrida, J., 2000, Of hospitality: Anne Dufourmantelle invites Jacques Derrida to respond, transl. R. Bowlby, Stanford University Press, Stanford.

Freud, S., 1950, 'Project for a scientific psychology', in S. Freud (ed.), The standard edition of the complete psychological works of Sigmund Freud, volume I (1886-1899): Pre-psychoanalytic publications and unpublished drafts, pp. 317-320, Imago Publishing Co., London.

Fromm, E., 1976, To have or to be?, Harper \& Row, New York.

Heidegger, M., 1969, Identity and difference, trans. J. Stambaugh, Harper \& Row, New York.

Horne, B., 2004, 'Articles: On the desire of the analyst', International Lacanian Review, viewed 02 June 2009, from http://www.lacanianreview.com

Lacan, J., 1966, 'Remarque sur le rapport de Daniel Lagache: "Pschanalyse et structure de la personnalite" [Note on the report of Daniel Lagache: "Psychoanalysis and the structure of personality"l', Ecrits, pp. 647-684, Seuil, Paris.

Lacan, J., 1974, Proceedings of the conference held at the French Cultural Centre, 30 March 1974, Rome.

Lacan, J., 1998a, Feminine sexuality: The Seminar of J. Lacan, Book $X X$, WW Norton \& Co., New York.

Lacan, J., 1998b, Encore - On Feminine sexuality, the limits of love and knowledge: The seminar of Jacques Lacan, Book XX, 1972-73, trans. B. Fink, Norton, New York.

Lacan, J., 2001, 'Radiophonie', in J. Lacan (ed.), Ecrits, pp. 403448, Seuil, Paris.

Lacan, J., 2006, Book XVII: The other side of pscyhoanalysis, trans. R. Grigg, WW Norton \& Co., New York.

Levinas, E., 1969, Totality and infinity: An essay on exteriority, trans. A. Lingis, Duquesne University Press, Pittsburgh.

Meylahn, J.-A., 2009, 'Responsibility, God and society: The cry of the other in the sacred texts as challenge towards responsible global citizenship', HTS Teologiese Studies/ Theological Studies 65(1), DOI: 10.4102/hts.v65i1.131.

Meylahn, J.-A., 2010, The church in the postmodern global village: Towards pastoral redemptive communities, volume two, Lambert Academic Publishing, Saarbrücken.

Miller,J-A., 'La passe: Conférence de Jacques-Alain Miller', paper presented at the fourth Congrès de l'AMP, Comandatuba Bahia, Brazil, August 9-12, 2004.

No Subject: Encyclopedia of psychoanalysis, n.d., Master-Signifier, viewed 19 June 2009, from http://nosubject.com/seminar_ XVII

Sharpe, M., 2006, Jacques Lacan, in Internet Encyclopedia of Philosophy, viewed 30 May 2009, from: http://www.iep. utm.edu/l/lacweb.htm

Verhaeghe, P., 1995, 'From impossibiity to inability: Lacan's theory on the four discourses', The Letter: Lacanian Perspectives on Psychoanalysis 3(Spring), 91-108.

Verhaeghe, P., 1999, Love in a time of loneliness: Three essays on drive and desire, Rebus Press, London.

Wajcman, G., 2003, The hysteric's discourse, viewed 12 June 2009, from http://www.lacan.com/hystericdiscf.htm

Žižek, S., 2006, Jacques Lacan's four discourses, viewed 02 June 2009, from http://www.lacan.com/zizfour.htm 